commonly, the hospital service. The extreme example is the unconscious patient kept alive only by the efforts of nursing and medical teams. Nevertheless, the existence of such tragedies does not deter surgeons from labouring to save the lives of gravely injured persons, for in most cases the outcome cannot be foretold in the early stage.

Though the standards of treatment of acute head injuries may not be uniform in Britain, there has been a great overall improvement, and the lessons learned in neurosurgical practice are widely employed. Rehabilitation of the severely injured is a different matter. Almost 30 years ago Cairns and Symonds showed the way by establishing a centre for convalescence and rehabilitation at Middleton Park in association with the Military Hospital for Head Injuries at Oxford. Unfortunately the experience gained has not been widely used in the National Health Service. The restoration of patients with head injuries requires a wide range of therapeutic aids, physiotherapy, occupational therapy, speech therapy, retraining, and continuing neurological supervision. These needs are best met in centres with staff who understand the patients' temperamental difficulties and defective intellectual functions. Those with substantial physical defects or who live at a distance need residential accommodation. Most of these requirements could be met in well-equipped general hospitals with appropriately experienced staffs, but residential accommodation is rarely provided and integration of the treatment programme is often lacking. Lewin's suggestion that a medical social worker should bridge the gap between clinicians and other workers engaged points the way to an inexpensive method of improving the service, but there is a clear need to develop rehabilitation facilities more widely throughout the country.

However good the services, there will always be a substantial group of patients, perhaps 750 a year, who will be able to work only at a reduced level of efficiency, and another group of some 450 who will never work again. There will also be a few who will need permanent hospital care. London writes of the unhappiness caused within families by serious changes in temperament and behaviour in patients after head injuries, and this is a problem only too familiar to doctors. While supportive psychotherapy and medication can be helpful in these tragic cases, in the current state of our knowledge the problems these cases present are insoluble. The weight of the load that a family can bear must be recognized, and when it proves too great the patient should be removed to a hospital or to a mental hospital, as circumstances dictate, for long-term care. Thus if the overall incidence is $1 \%$, there are also each year about 1,000 new cases of epilepsy due to intracranial trauma. In many cases the seizures can be well controlled, but as a further cause of disability they are by no means negligible.

Prevention of accidents is a matter ultimately for every citizen, but doctors especially must continue to encourage all measures designed to reduce accidents on the roads, in industry, and elsewhere. The work of Professor Gissane and his colleagues has shown how in many cases the medical profession can point the way to accident prevention. We should also ensure that the many problems of patients with head injuries, including their need for more organized rehabilitation facilities, are appreciated by the Ministry of Health, boards of governors, and regional hospital boards. The national problem is too large to be ignored.

' Lewin, W., Brit. med. F., 1968, 1, 465.

2 London, P. S., Ann. roy. Coll. Surg. Engl., 1947, 41, 460.

\section{Pott's Paraplegia}

In 1799 Percivall Pott described paraplegia caused by spinal tuberculosis and the basis of its cure-drainage of the abscess. Even when surgical decompression of the spinal cord became technically possible the operation remained hazardous for many years because of the risk of dissemination of the disease. As the value of improved nutrition and rest as essential parts of treatment became apparent the chances of survival from operation improved, so that by the midthirties $^{12}$ the risks of surgery were much outweighed by the advantages of decompression. The introduction of antituberculous chemotherapy completed the trend towards an active surgical approach. ${ }^{3}$

Nowadays a surgeon can gain experience in the management of tuberculosis of the bones and joints only if he chooses to work in less developed countries. ${ }^{4-6}$ Some of the last series published in Britain ${ }^{7}$ confirmed the growing belief in early surgery not only for Pott's paraplegia but also for its predecessor spinal tuberculosis (and it is irrational to consider the basic disease process and its grave complication separately). As spinal tuberculosis has become less and less common the chances of repeating useful clinical investigations in Britain have become remote. Nevertheless, the disease could return if the mycobacterium became increasingly virulent and resistant to antibiotics. ${ }^{9}$

The classical condition described by Pott is a paraplegia of early onset, in which pressure is due to tuberculous pus, granulation tissue, and necrotic material ; there may also be vertebral collapse. Treatment is by immediate administration of full antituberculous chemotherapy followed by early exploration, evacuation of the pus, and stabilization by bonegrafting if necessary. With such treatment the prognosis for recovery is excellent. If neurological symptoms or signs are present the patient should be kept in bed. After operation there should be a long course of chemotherapy. Late onset of the paraplegia can be due to compression by scarring or sometimes to pressure from the bony ridge of the kyphosis; these forms of the disease have a worse prognosis.

There is less agreement on the choice of operation. A transthoracic approach to the dorsal spine is widely favoured, since contamination of the interpleural space is not commonly followed by tuberculous pleurisy. The alternative lateral approach to the thoracic spine developed from the technique of simple decompression of an abscess ; the sides of the bodies and the spinal canal can be fully exposed if some pedicles are removed. This approach is easier when kyphosis is present, and indeed this deformity makes the transpleural approach less efficient.

When the disease focus is exposed the necrotic material can be removed, so decompressing the area and at the same time reducing the risk of chronic infection. The cavity may then be packed with a bone graft, though some surgeons prefer to perform a formal type of arthrodesis using autogenous rib. ${ }^{10}$ If an excessive quantity of bone is removed

\footnotetext{
Alexander, G. L., Proc. roy. Soc. Med., 1946, 39, 730.

2 Capener, N., f. Bone ft Surg., 1954, 36B, 173.

3 Paus, B., Acta orthop. scand., 1964, Suppl. No. 72.

- Dickson, J. A. S., f. Bone ft Surg., 1967, 49B, 682.

Guirguis, A. R., f. Bone ft Surg., 1967, 49B, 658.

6 Kohli, S. B., f. Bone ft Surg., 1967, 49B, 668.

Konstam, P. G., Tubercle (Lond.), 1964, 45, 179.

* Shaw, N. E., and Thomas, T. G., Brit. med. f., 1963, 1, 162.

- Capener, N., f. Bone ft Surg., 1967, 49B, 605.

"Cook, W. A., Shaw, R. R., Webb, W. R., Clark, W. K., and Shah, H. 'H., Amn thorac. Surg., 1967, 4, 291
} 
the spinal column may be weakened, and whenever possible the posterior elements should be preserved. Whatever the approach, the aim of treatment is to replace the diseased tissues with sound, healthy bone.

\section{Restraint of Professional Activities}

It is an old principle of law that contracts in restraint of trade are unenforceable unless they are deemed to be reasonable in the public interest and in the interest of the parties. For this reason restrictive covenants incorporated into the sale of a business or a professional practice have to be drawn with care. For centuries the courts have decided that, subject to certain exceptions, it is wrong that a man should be deprived of the opportunity of earning a living in the manner of his choosing. But until a recent case this principle had not been applied to the rules of professional bodies regulating the conduct of members, though every professional body imposes restraints on the money-making activities of its members.

The House of Lords has now confirmed the decisions of Mr. Justice Pennycuick ${ }^{1}$ and the Court of Appeal $^{2}$ declaring it to be outside the powers of the Pharmaceutical Society of Great Britain to enforce a motion of the Society designed to place restrictions on the siting and trading activities of new pharmacies and extensions of existing pharmacies. The restrictions on sales were intended to cover goods other than the traditional toiletries and photographic equipment. It is worth noting that none of the judges involved in this case accepted the submission made on behalf of the Pharmaceutical Society that the doctrine of "restraint of trade" did not arise.

The litigation was begun at the suit of Mr. R. C. Miller Dickson, a member of the Pharmaceutical Society and a retail director of Boots Pure Drug Co. Ltd. He wanted to resist the promotion of the Pharmaceutical Society's policy aimed at imposing new restrictions on the trading activities of pharmacists. The policy was formulated in a motion passed at a special general meeting of the Society at the Albert Hall on 25 July 1965.

In giving his judgement Lord Upjohn ${ }^{3}$ suggested that the reason why the doctrine of " restraint of trade" had not been previously applied to the rules of professional bodies was that a profession called on its members to serve the public by offering them highly technical and always confidential services which required a different standard of conduct from that of the tradesman. Therefore the public's reliance on professional men is such that a different and more restrictive code is acceptable. The professional man must submit to some restraints of trade such as prohibitions against advertising and undercutting charges. In other words, though the law on restraint of trade applies to professional rules of conduct, the courts will be more ready to accept such restraints as being reasonable than they would if the restraints were on trading contracts and contracts of service.

In the present case the Pharmaceutical Society had declined to be drawn into a detailed examination of whether or not the restrictions imposed by the motion of 25 July 1965 were reasonable. It may be that if the Society had chosen to

1 Brit. med. F., 1966, 2, 181.

2 Brit. med. F., 1967, 1641.

- The Times, 30 May 1968. fight the case in another way it might have shown that they were. But what is reasonable or unreasonable restraint ? It appears that the House of Lords did not decide where the onus of proof of this question lies. The normal rule is that the person wanting to enforce a restraint of trade has the burden of justifying it and showing it to be reasonable as between the parties concerned. Without actually rejecting a submission that the same rule should apply to this case, Lord Reid expressed doubts whether the rule did apply when restraints existed as part of a code of professional conduct. As he pointed out, if the ordinary rule were to apply, any member of a profession who wanted to make more money by disregarding some long-standing rule of professional conduct could require the restraint to be justified without himself having to prove that the rule was unreasonable. Clearly this question of the onus of proof will be of great practical importance to the professions.

\section{Doctors in the Armed Forces}

In the early 1960s, after the end of National Service, recruitment of doctors into the armed Forces was very poor. In 1962 the Government and the B.M.A. together worked out a "new deal" for Service doctors, and cadetships were introduced for medical students. The Government had accepted that "to attract newly qualified young doctors in adequate numbers and of good quality they must be offered a substantial lead over the remuneration which they could expect in civilian life." 1 General duties medical officers aged 26 or more were offered salaries some $16 \%$ higher than the average earnings of an N.H.S. general practitioner. As a result there was a dramatic improvement ${ }^{2}$ in the recruitment of doctors, many of whom signed on for periods of up to 16 years.

The pay of Service personnel is reviewed every two years, but after 1962 successive reviews made it clear that the pay of Service doctors was linked to that of N.H.S. general practitioners. All went smoothly until the biennial review of April 1966, which awarded increases of pay of about $18 \%$ to non-medical officers. The Review Body, in its Seventh Report published in May 1966, gave general practitioners a rise of about $30 \%$ in pricing the new contract (in addition to an interim rise of $9 \%$ given in 1965). If the differential established in 1962 was to be maintained a comparable rise should have been given to Service doctors, but in the atmosphere of the wages standstill they were given $10 \%$ only.

This cynical breach of faith caused widespread resentment among Service doctors, and the B.M.A. Council decided ${ }^{3}$ that the Association could no longer recommend the Services as a satisfactory career for doctors and refused to accept advertising for the armed Forces in the B.M.7. Recruitment fell off, serving medical officers who could do so retired prematurely, and by September 1967 there was an overall deficiency ${ }^{4}$ of 266 Service doctors $(14.2 \%)$.

In November 1967 the National Board for Prices and Incomes was asked to keep the pay of Service personnel under continuous review, and its first report ${ }^{4}$ on Service pay

\footnotetext{
Brit. med. F., 1962, 1, 1191.

Brit. med. 7. Suppl., 1963, 1, 247.

3 Brit. med. 7. Suppl., 1967, 2, 5.

- National Board for Prices and Incomes: First Report on Standing Reference on the Pay of the Armed Forces, 1968. H.M.S.O., London.
} 